to confer the degree of bachelor of arts. The first students were admitted in 1950 and will complete their four-year course of study next term. The ceremony will take place in the College Hall at Keele.

\section{European Convention on the Equivalence of University Entrance Examinations}

RFPLYING to a question in the House of Commons on March 29, Mr. Anthony Nutting, Joint UnderSecretary of State for Foreign Affairs, stated that the United Kingdom instrument of ratification of the European Convention on the Equivalence of University Entrance Examinations was deposited with the Secretary-General of the Council of Europe on March 22, 1954. Copies of the Convention were presented to Parliament on January 12 as Command Paper 9039. Under the Convention, for the purpose of admission to universities in its territory that are subject to State control in the matter of entry, each contracting Government undertakes to recognize the equivalence of those diplomas awarded in the territories of the other contracting parties which constitute a requisite qualification for admission to similar institutions in those territories. Admission to any university is subject to the availability of places ; and the Governments undertake to transmit the text of the Convention to universities in their territory that are not subject to State control in the matter of entry, and to endervour to obtain acceptance of the principles of the Convention by such universities.

\section{Information on Atomic Weapons}

IN a statement in the House of Commons on March 23, the Prime Minister said that there was a constant interchange of ideas between H.M. Government and the U.S. Government both direct and through N.A.T.O., and that he had had intimate correspondence and conversations with President Eisenhower on the group of stupendous problems and perils comprised in atom and hydrogen bomb developments. After commenting on the remarkable restraint of the Press, he said that he hoped and trusted that the nation and thinking people in it would not in any way under-rate the overwhelming consequence of the developments which are taking place. Answering questions in the House of Commons on March 30, Sir Winston added that our knowledge of the American experiments is necessarily limited, and the U.S. Government is prevented by its own legislation from divulging secret information about. them. From our own scientific knowledge he could say that there is no foundation for the suggestion that these explosions are "incalculable" in the sense that those making the tests are unable to set limits to the explosive power of the hydrogen bomb or to calculate in advance what the main effects will be. The restrictions imposed by the United States law also make it impracticable for further tests to be the subject of international consultation or control ; but he hoped that it would be found possible within the limits of existing U.S. legislation to give us information about what occurred in the present test series. With regard to the suggestion that he should attempt to persuade the U.S. Government to abandon this series of experimental explosions of hydrogen bombs, he said we have no power to stop this. No satisfactory arrangements could be made to limit the use of atomic weapons except as part of an international agreement on disarmament as a whole, and there could be no security in such an agreement unless it included provision for effective inspection and enforcement.

The agreement between the United States and the United Kingdom Governments relating to atom bomb research and development, made at Quebec in August 1943 , to which the Prime Minister referred in his subsequent speech in the House of Commons on April 5, has been published as a White Paper (Cmd. 9123). After agreeing that the atom bomb would not be used against third parties without each other's consent and that information relating to it would not be communicated to third parties except by mutual consent, it provided for full and effective interchange of information and ideas relating to scientific research and development between those in the two countries engaged in the same sections of the field, as well as for complete interchange of information and ideas on all sections of the project between members of the Combined Policy Committee set up in Washington, and their immediate technical advisers.

\section{Oxford Meeting of the British Association}

THE preliminary programme has now been issued for the Oxford meeting of the British Association to be held during September 1-8, under the presidency of Dr. E. D. Adrian, whose presidential address will be on "Science and Human Nature". The presidents of sections and the titles of their sectional addresses are as follow : Section A (Mathematics and Physics), Sir John Cockcroft, "Recent Developments in H.ighEnergy Physics"; Section B (Chemistry), Sir John Lennard-Jones, "New Ideas in Chemistry" ; Section C (Geology), Dr. C. J. Stubblefield, "The Relationship of Palæontology to Stratigraphy"; Section D (Zoology), Dr. G. R. de Beer, "Archæopteryx and Evolution" ; Section E (Geography), Prof. J. A. Steers, "The Coast and the Geographer"; Section F (Economics), Prof. E. A. G. Robinson, "The Changing Structure of the British Economy"; Section G (Engineering), Dr. Willis Jackson, "New Materials in Engineering"; Section H (Anthropology and Archæology), Sir Mortimer Wheeler, "Archæology in Africa" ; Section I (Physiology), Prof. A. D. Macdonald, "The Relief of Pain" ; Section J (Psychology), Prof. L. S. Hearnshaw, "Recent Studies in the Psychology of Thinking"; Section K (Botany), Prof. W. H. Pearsall, "Growth and Reproduction"; Section L (Education), Mr. Ronald Gould, "The Teacher in the Twentieth Century"; Section M (Agriculture), Dr. R. E. Slade, "Agriculture: the Industry and the Science"; Section X (Assembly of Corresponding Societies), Dr. C. B. Williams, "Phenology: the Sequence of Events in the Biological Seasons". Copies of the programme can be obtained from the Secretary, British Association, Burlington House, Piccadilly, London, W.1.

\section{Handbooks for Museum Curators}

THE museum profession has always lacked a complete series of authoritative handbooks describing accepted principles concerning administration, display and technique in museums and art galleries. True, that in geology and certain other matters with which the museums are concerned there are outstanding exceptions but, by and large, students for the diploma of the Museums Association and indeed those more senior in the vocation lack accredited text-books. To meet this need an editorial panel of distinguished directors and others under the chairmanship of Dr. D. B. Harden has been entrusted with the production 